A N N A L E S

UNIVERSITATIS MARIAE CURIE-SKŁODOWSKA

LUBLIN - POLONIA

VOL. LXVI, 1

SECTIO G

2019

Uniwersytet Marii Curie-Skłodowskiej w Lublinie

MAREK KURYŁOWICZ

marek.kurylowicz@poczta.umcs.lublin.pl

ORCID: 0000-0001-5339-5489

\title{
Aequitas i iustitia w rzymskiej praktyce prawnej
}

Some Reflections on aequitas and iustitia in Roman Jurists' Concepts

I.

Punktem wyjścia jest tu powszechnie znane z justyniańskich Digestów rzymskie określenie prawa jako umiejętności odnajdywania i stosowania tego, co dobre i słuszne ${ }^{1}$.

Ulpianus D. 1,1 pr.: Iuri operam daturum prius nosse oportet, unde nomen iuris descendat, est autem a iustitia appellatum: nam, ut eleganter Celsus definit, ius est ars boni et aequi.

(Zamierzając studiować prawo, należy najpierw dowiedzieć się, skąd pochodzi nazwa prawa. Jest ono tak nazwane od sprawiedliwości, albowiem, jak to wytwornie określa Celsus, prawo jest sztuką [stosowania] tego, co dobre i słuszne) $)^{2}$.

U podłoża pojęcia prawa, w skład którego wchodziła zasada słuszności aequitas, leżała według rzymskich jurystów sprawiedliwość (iustitia) jako stała i niezmienna wola przyznawania każdemu należnego mu uprawnienia: Iustitia

1 Por. wstępnie: M. Kuryłowicz, Prawo rzymskie. Historia-tradycja-współczesność, Lublin 2003, s. 161-165 oraz literaturę przywołaną na s. 172-173; idem, Prawo rzymskie jako ideat prawa dobrego i sprawiedliwego, „Przegląd Prawa Egzekucyjnego” 2010/2011, t. 10, s. 5-20 i przywołana tam literatura (wersja niemiecka: Das römische Recht als Ideal eines richtigen und gerechten Rechts, "Comparative Law Review" 2013, Vol. 16, DOI: https://doi.org/10.12775/CLR.2013.024, s. 247-266).

2 O Celsusie i jego definicji zob. także: H. Hausmaninger, Publius Juventius Celsus: Persönlichkeit und juristische Argumentation, [w:] Aufstieg und Niedergang der Römischen Welt, Bd. 2, Berlin-New York 1976, s. 399-403; P. Voci, Ars boni et aequi, "INDEX" 1999, No. 27, s. 1-22. 
est constans et perpetua voluntas ius suum cuique tribuendi (Ulp. D. 1,1,10 pr.) $)^{3}$. Łącznikiem między prawem i sprawiedliwością były w tym ujęciu zasady postępowania według prawa - iuris praecepta: honeste vivere, alterum non laedere, suum cuique tribuere (,uczciwie żyć, drugiego nie krzywdzić, każdemu oddać to, co mu się należy") ${ }^{4}$. Pojęcia te łączą się z definicjami ius i iustitia, albowiem dobro (bonum) to przecież nic innego, jak nikomu nie wyrządzać krzywdy (neminem laedere), a słuszność (aequum) i sprawiedliwość to przyznanie każdemu, co mu się należy (ius suum cuique tribuere) . $^{5}$.

Uogólnione znaczenia aequitas i iustitia wyrażają się ponadto w różnych sentencjach spotykanych w rzymskich tekstach prawniczych oraz w pozaprawnej literaturze łacińskiej. Stanowią one jednocześnie ważne do dzisiaj argumenty i topiki $\mathrm{w}$ rozumowaniach oraz uzasadnieniach prawniczych ${ }^{6}$. Tak np. znaczenie aequitas w prawie rzymskim zostało podkreślone wypowiedzią: In omnibus quidem, maxime tamen in iure, aequitas spectanda est (,We wszystkich sprawach, ale szczególnie w prawie, należy uwzględniać słuszność”) ${ }^{7}$. Powtórzył tę zasadę z uwzględnieniem iustitia cesarz Konstantyn w swojej ustawie z 314 r. n.e.: Placuit in omnibus rebus praecipuam esse iustitiae aequitatis, quam stricti iuris rationem (,Jest przyjęte, że we wszystkich sprawach trzeba uwzględniać

3 Także w Instytucjach justyniańskich - Inst. 1,1 pr. O tej definicji zob. wstępnie: Regulae iuris. Łacińskie inskrypcje na kolumnach Sądu Najwyższego Rzeczypospolitej Polskiej, red. W. Wołodkiewicz, Warszawa 2001, s. 93-96. Zob. także: U. von Lübtow, Die Anschauungen der römischen Jurisprudem über Recht und Gerechtigkeit, [w:] Studi in onore di C. Sanfilippo, t. 4, Milano 1985, s. 517; W. Waldstein, Zu Ulpians Definition der Gerechtigkeit, [w:] Festschrift für Werner Flume, Köln 1978, s. 213 i n.

4 D. 1,1,10,1. Por. ostatnio: M. Kuryłowicz, Alterum non laedere i uniwersalność rzymskich zasad prawa, [w:] Państwo i prawo w dobie globalizacji, red. S. Sagan, Rzeszów 2011, s. 171-181 i przywołana tam literatura.

5 Por. wyżej przypisy 1-4, a ponadto: J. Maifeld, Die ,, aequitas “ bei L. Neratius Priscus, Trier 1991; F. Gallo, Diritto e giustizia nel titolo primo dei Digesta, "Studia et Documenta Historiae et Iuris” 1988, Vol. 56, s. 1-36; U. von Lübtow, De iustitia et iure, „Savigny-Zeitschrift für Rechtsgeschichte. Romanistische Abteilung“ 1948, Bd. 66(1), DOI: https://doi.org/10.7767/zrgra.1948.66.1.458, s. 525 i n.; A. Polaček, Zum Gerechigkeitsgedanken im römischen Recht, „Savigny-Zeitschrift für Rechtsgeschichte. Romanistische Abteilung“ 1960, Bd. 77(1), DOI: https://doi. org/10.7767/zrgra.1960.77.1.160, s. 160-181.

6 O sentencjach łacińskich (rzymskich) związanych z aequitas zob. m.in. M. Kuryłowicz, Rzymskie sentencje prawnicze o człowieku, sprawiedliwości i prawie, „Palestra” 1988, nr 7, s. 71 i n.; idem, Etyka i prawo w sentencjach rzymskich jurystów, [w:] W kręgu problematyki władzy, państwa i prawa (ksiega jubileuszowa prof. H. Groszyka), red. J. Malarczyk, Lublin 1996, s. 125-134. Ponadto: Łacińska terminologia prawnicza, red. J. Zajadło, Warszawa 2009, s. 18, 36, 49; Regulae iuris..., s. 12, 24, 27, 35, 41, 49.

7 Paulus D. 50,17,90. Por. W. Bojarski, W. Dajczak, A. Sokala, Verba iuris. Reguty i kazusy prawa rzymskiego, Torun 2007, s. 37 (nr 115); K. Burczak, A. Dębiński, M. Jońca, Eacińskie sentencje i powiedzenia prawnicze, Warszawa 2013, s. 115 (nr 122); T. Palmirski, O różnych regułach dawnego prawa, „Zeszyty Prawnicze” 2006, z. 6.2, s. 256, 311. Ponadto: Regulae iuris ..., s. 91-92. 
szczególnie sprawiedliwość i słuszność niż ścisły sens prawa") ${ }^{8}$. Prawnik rzymski z przełomu II i III w. n.e. Marcianus (D. 48,17,1 pr.) sformułował natomiast w odniesieniu do prawa karnego ponadczasową w swym znaczeniu zasadę: Inaudita causa quemquem damnari aequitatis ratio non patitur („Poczucie słuszności nie pozwala na skazanie kogokolwiek bez rozpoznania sprawy i jego wysłuchania”). Myśl tę znajdujemy już u Lucjusza Anneusza Seneki (Filozofa - I w. n.e.) w tragedii Medea (199-200): Qui statuit aliquid parte inaudita altera, aequum licet statuerit, haud aequus fuit (,Kto wydaje wyrok bez wysłuchania drugiej strony, jest niesprawiedliwy, chociażby nawet wydał wyrok słuszny") ${ }^{9}$. Na podstawie tekstów prawa rzymskiego późniejsi komentatorzy sformułowali ponadto sentencję: Aequitas praefertur rigori („,Słuszność przed surowością”, czyli „Słuszność powinna być stawiana przed srogością [prawa]") ${ }^{10}$. Takie stwierdzenia były traktowane przede wszystkim jako wytyczne dla jurystów i sędziów, którzy powinni kierować się nie tylko literą prawa, lecz również normami słuszności, zwłaszcza tam, gdzie konkurowały one z przepisami prawa ścisłego ${ }^{11}$. Myśl o korygowaniu rygorów prawa poprzez względy słuszności leży też u podłoża twierdzeń sprzeciwiających się nadużyciu prawa, tj. gdy uprawniony podmiot wykonuje swoje uprawnienie w sposób nieprzynoszący mu pożytku, a powodujący u innych szkodę $^{12}$. Generalną podstawę, obok słuszności, stanowi także wspomniany już nakaz (praeceptum iuris), by nikogo nie krzywdzić (alterum non laedere).

Swój uniwersalny wyraz w sentencjach i paremiach łacińskich znalazła również iustitia, która jako pojęcie sprawiedliwości ma głębsze umocowanie historyczne i filozoficzne. Sama definicja, przypisywana według D. 1.1.10,1 Ulpianowi, ma wcześniejszą wersję w wypowiedzi Cycerona: Iustitia cernitur in suo cuique tribuendo (,Sprawiedliwość urzeczywistnia się w oddawaniu każdemu tego, co mu się należy") ${ }^{13}$. U tego filozofa i mówcy rzymskiego spotkać można też

8 C. 3,1,8. Na temat tej zasady zob. szerzej: Regulae iuris..., s. 41-43. Ostatnio również: K. Burczak, A. Dębiński, M. Jońca, op. cit., s. 107 (nr 43). Szerzej: K. Amielańczyk, Obecność i znaczenie zasady stuszności w rzymskim prawie karnym, „Studia Iuridica Lublinensia” 2011, t. 15, s. 29-44.

9 Por. M. Kuryłowicz, Wokót pojęcia aequitas w prawie rzymskim, "Studia Iuridica Lublinensia" 2011, t. 15, s. 23-24; A. Wacke, Audiatur et altera pars. Juristische Arbeitsblätter, Berlin 1980, s. 594.

10 Glossy do D. 15,1,32; 39,3,2,5; 47,2,62,5. Por. D. Liebs, Lateinische Rechtsregeln und Rechtssprichwörter, München 1986, s. 26 (nr 54).

11 Por. m.in. A. Polaček, Zum Gerechigkeitsgedanken im römischen ..., s. 28. Autor zwraca uwagę na znaczenie tych zasad jako dyrektyw dla sędziego.

12 Szerzej na ten temat: F. Longchamps de Bérier, Nadużycie prawa w świetle rzymskiego prawa prywatnego, Wrocław 2004 (wyd. 2, Wrocław 2007).

13 Cicero, De finibus 5,23,67 oraz De inventione 2,53,160. Zob. K. Burczak, A. Dębiński, M. Jońca, op. cit., s. 127 (nr 240); Regulae iuris..., s. 94. O znaczeniu pism Cycerona zob. m.in. D. Nörr, Cicero-Zitate bei den klassischen Juristen. Zur. Bedeutung literarischer Zitate bei den Juristen und zur Wirkungsgeschichte Ciceros, [w:] Ciceroniana. Atti del III Colloquium Tullianum, Roma 1978, s. 111-150. 
sentencje: Iustitia omnium est domina et regina virtutum („Sprawiedliwość jest panią i królową wszelkich cnót") ${ }^{14}$ oraz Iustitiae partes sunt non violare homines, verecundiae non offendere („Obowiązkiem sprawiedliwości jest nie krzywdzić ludzi, obowiązkiem przyzwoitości - nie urażać") ${ }^{15}$.

Korzenie historyczne sięgają zresztą znacznie głębiej, ponieważ pojęcie sprawiedliwości zawsze było traktowane jako mądrość przyjęta w państwie, społeczeństwie i prawie. W tym sensie znana była już w Starym Testamencie, Kodeksie Hammurabiego oraz prawach starożytnego Egiptu ${ }^{16}$. Próbę filozoficznego zdefiniowania, czym jest sprawiedliwość, podjął również Arystoteles, ale przytoczona wyżej definicja łacińska wyraża treść całkowicie rzymską. Definicja Ulpiana, nawiązująca do filozoficznych rozważań Cycerona, byłaby zatem rzymskim wyrażeniem tego samego uniwersalnego pojmowania prawa jako sposobu rozstrzygania o tym, co dobre i słuszne w realizacji odwiecznej i ponadczasowej idei sprawiedliwości ${ }^{17}$.

$\mathrm{Na}$ czoło sentencji związanych ze sprawiedliwością wybija się: Iustitia est fundamentum regnorum („Sprawiedliwość jest podstawą królestw [państw]”) ${ }^{18}$. Ta dewiza dynastii Habsburgów znajduje swoje źródło w starotestamentowej Księdze Przysłów 25,5 (Salomon): „Oddal bezbożnika sprzed królewskiego oblicza, a tron jego umocni się przez sprawiedliwość" 19 . Nowożytnym odpowiednikiem jest umieszczony na gmachu sądów przy al. Solidarności w Warszawie napis: „Sprawiedliwość jest ostoją mocy i trwałości Rzeczypospolitej”, zaczerpnięty z dzieła Andrzeja Frycza Modrzewskiego O poprawie Rzeczypospolitej. W tym kontekście warto przypomnieć, iż iustitia znalazła się również w inskrypcji umieszczonej na krzyżu w sali Trybunału Koronnego w Lublinie: Iusticias vestras iudicabo („Osądzę waszą sprawiedliwość"). Nawiązywała ona także do Starego Testamentu i Proroctwa Ezechiela 7,27: „Według drogi ich uczynię im, a według sądów ich osądzę je"20. Miała ona przypominać sądzącym się stronom oraz orzekającym sędziom, iż jest jeszcze wyższy Sędzia, który oceni ich czyny i osądzi wydane wyroki²1.

14 Cicero, De officiis 3,28.

15 Cicero, De officiis 1,99,6. Zob. K. Burczak, A. Dębiński, M. Jońca, op. cit., s. 127 (nr 241, 243). Pojęcie przyzwoitości w obecnym życiu publicznym wyraźnie zanika.

16 Por. wstępnie: M. Kuryłowicz, Prawa antyczne. Wykłady z historii najstarszych praw świata, Lublin 2006 (ze wskazówkami bibliograficznymi na s. 207-222).

17 Por. W. Waldstein, Zu Ulpians Definition..., Fst. Flume, s. 217-218. Zob. także: Regulae iuris..., s. 94.

18 W. Bojarski, W. Dajczak, A. Sokala, op. cit., s. 41 (nr 146); K. Burczak, A. Dębiński, M. Jońca, op. cit., s. 128 (nr 246).

19 D. Liebs, op. cit., s. 106 (nr 196).

20 Zob. Regulae iuris..., s. 67-68.

21 Według jednej z lubelskich legend, mającej wsparcie w historycznych źródłach, podczas procesu w roku 1637 (1638?) przegrana wdowa, której sprawę stronniczo osądzili przekupieni sędziowie, wzniosła ręce właśnie do krucyfiksu wiszącego w sali sądowej i zawołała: „Gdyby diabli sądzili, wydaliby sprawiedliwszy wyrok!”. I tak się stało - o północy w sali posiedzeń trybunalskie- 
Wracając do antyku, z rzymskiej myśli prawnej może pochodzić sentencja: Iustitia non debet claudicare („Sprawiedliwość nie powinna kuleć”) ${ }^{22}$. Brakuje wprawdzie tutaj źródłowego potwierdzenia, ale na jej sens składają się m.in. wypowiedzi cesarzy rzymskich ujęte w sentencję: Expedit rei publicae ut finis sit litium (,Jest z korzyścią dla państwa, aby procesy nie trwały zbyt długo [by zostały zakończone]") 23. Dzisiaj sentencja o niekulejącej sprawiedliwości oznacza przede wszystkim dążenie do zabezpieczenia prawidłowości postępowania sądowego, co wiąże się $\mathrm{z}$ instytucjonalną i procesową ochroną praw jednostki. Wynika z tego zarówno prawo podmiotowe, gwarantujące każdemu ochronę jego praw przed sądem, jak i obowiązek bezstronnego, niezawisłego i sprawiedliwego rozpoznania sprawy przez organy państwowe, $\mathrm{i}$ to bez nieuzasadnionej zwłoki ${ }^{24}$. Temu powinny służyć reformy systemu sądownictwa i całego wymiaru sprawiedliwości, ale - jak pokazuje historia - różnie z tym bywało i bywa. Przytoczę tu w całości krótki felieton Macieja Jońcy, profesora i obecnie kierownika Katedry Prawa Rzymskiego na Katolickim Uniwersytecie Lubelskim Jana Pawła II, opublikowany w „Dzienniku Gazecie Prawnej” z dnia 16 sierpnia 2016 r. pt. Źli sędziowie, czyli czego nas uczy historia antyczna:

go sądu pojawiły się zagadkowe postaci, które wydały wyrok na korzyść kobiety. Dla jego przypieczętowania diabelski sędzia oparł się ręką o stół, wypalając na nim ślad dłoni. Wówczas to Chrystus na krzyżu w sali rozpraw odwrócił głowę, żeby nie patrzeć, jak diabelskie sądy są sprawiedliwsze od ludzkich. Krzyż Trybunalski do dziś znajduje się w jednej z kaplic w Archikatedrze, a stół z wypaloną czarcią łapą stoi w muzeum na lubelskim Zamku. Por. M. Dobrowolska, Trybunat Koronny w Lublinie 1578-1794, Lublin 1994, s. 49 (legenda o sądzie diabelskim); Ilustrowany przewodnik po Lublinie, Lublin 1931 (reprint), s. 60, przypis 1. Zob. także: W. Witkowski, Lublin Trybunalski, [w:] Lublin w dziejach i kulturze Polski, Lublin 1997, s. 129-141.

22 Por. K. Burczak, A. Dębiński, M. Jońca, op. cit., s. 128 (nr 249); D. Liebs, op. cit., s. 106 (nr 198); R. Tokarczyk, Przykazania etyki prawniczej. Księga myśli, norm i rycin, Warszawa 2009, s. 278 (rzymska sentencja prawnicza). Sformułowanie może pochodzić jednak z jurysprudencji angielskiej XVIII-XIX w. Formułowanym wówczas regułom (zasadom) prawnym, zaczerpniętym z lokalnej praktyki i nauki, nadawano postać łacińskiej sentencji dla dodania w ten sposób wypowiadanemu rozstrzygnięciu powagi i uczoności. Oparte często na tekstach rzymskich, jednak nie zawsze pochodziły bezpośrednio od jurysprudencji rzymskiej. Por. A. Stępkowski, Maksymy prawne na Wyspach Brytyjskich, [w:] Eacińskie paremie w europejskiej kulturze prawnej i orzecznictwie sądów polskich, red. W. Wołodkiewicz, J. Krzynówka, Warszawa 2001, s. 71-107. Zob. także: M. Kuryłowicz, Ex iniuria ius non oritur. Szkic do dziejów zasady, [w:] Ius est a iustitia appelatum. Księga jubileuszowa dedykowana Profesorowi Tadeuszowi Wiśniewskiemu, red. T. Ereciński, J. Gudowski, M. Pazdan, M. Tomalak, Warszawa 2017, s. 1239-1250.

${ }^{23}$ W innej wersji: Interest rei publicae ut finis sit litium - zob. K. Burczak, A. Dębiński, M. Jońca, op. cit., s. 75 (nr 88), 119 (nr 154); D. Liebs, op. cit., s. 68 (nr 63), 98 (nr 121).

24 Zob. A. Łazarska, Rzetelny proces cywilny, Warszawa 2012, s. 74 (z powołaniem się na zasady: iustitia nemini neganda [,nikomu nie można odmawiać dostępu do sprawiedliwości”] oraz iustitia non debet claudicare). Por. M. Czecharowski, Iustitia non debet claudicare, „Jurysta” 2002, nr 7-8, s. 43. 
W V wieku naszej ery prawo rzymskie przybrało na Zachodzie postać gmatwaniny ustaw: niezrozumiałych, przeczących sobie wzajemnie, obrażających i wygrażających wszystkim, którzy śmieli nie podzielać wizji wszechwiedzącego władcy. Smutek przenika czytelnika podczas lektury tekstów zebranych w Kodeksie Teodozjusza z 438 roku.

Niedługo od publikacji tej monumentalnej kompilacji niewydolny organizm polityczny, z którym jego obywatele już dawno temu przestali się utożsamiać, z łoskotem osunął się na ziemię i skonał. Wydaje się, że katastrofę musieli przeczuwać również ówcześni władcy. Jak bowiem można inaczej wyjaśnić te wszystkie przejawy pychy i arogancji? Co tłumaczy nieustanne groźby, nagonki i poszukiwania winnych?

Eksponowane miejsce wśród adresatów cesarskich inwektyw zajmują... sędziowie. Pokuszę się o krótkie streszczenie wizerunku orzekających, jaki wyłania się z treści poźnoantycznych ustaw. Władcy nazywają ich perwersyjnymi. Zajmują się oni jedynie jątrzeniem, a skutkiem ich działań jest eskalacja niepokojów. Dlatego ci, którzy sprzeciwiają się władzy, są wichrzycielami, a tym samym... publicznymi wrogami. Nie brakuje sugestii, że jest to środowisko zdegenerowane i przeżarte korupcją. Cechami, jakimi odznaczają się sędziowie, są bezczelność, nieumiarkowanie, szaleństwo i zatwardziałość. Cechuje ich również nieumiarkowany i niczym nieuzasadniony upór. Ich działania to podłość. Wyroki zyskują miano przestępstwa, niegodziwości, łajdactwa, grzechu oraz skazy. Działania godzące w autorytet władzy opisuje ustawodawca jako uzurpację i bezprawie osób zaślepionych. To się mogło podobać, prawda? Na użytek onieśmielonej gawiedzi poźnoantyczni władcy z upodobaniem wygrażali w swoich ustawach sędziom, co nie przeszkadzało im zarazem podkreślać własnego przywiązania do... prawa. Jeszcze cesarz Majorian w 458 roku przekonywał, że nic złego w państwie się nie dzieje. „Nasza rzeczpospolita chroniona jest orężem, prawami i nienaruszoną czcią dla religii, i z nich czerpie korzyści" - pisał w jednej ze swoich ustaw, choć smutny koniec był już w zasięgu wzroku. Wkrótce Rzym umarł, ale nie prawo rzymskie. Przetrwał również poklasyczny sposób narracji, który w rodzimym dyskursie politycznym przeżywa ostatnio prawdziwy renesans.

Zwykle twierdzę, że każda forma recepcji antycznych wzorców we współczesnym świecie jest dobra. Tym razem jednak nie. Wypowiedzi polityków na temat środowiska sędziowskiego w Polsce sprawiają, że jesteśmy świadkami przerażającego regresu. Nie powinniśmy do tego wracać.

II.

W praktyce kryteria dobra, słuszności i sprawiedliwości stanowiły rzeczywisty element rozważany przez jurystów przy wydawaniu opinii prawnych. Wielokrotnie powołują się oni w uzasadnieniach swoich decyzji, że dane rozstrzygnięcie jest słuszne (aequum) albo niesłuszne (iniquum), dobre (bonum) lub sprawiedliwe (iustum). Te wartości musiały więc leżeć u podstaw działania jurysty, który kształtował swoimi opiniami prawo, a w sumie u podstaw działania całej jurysprudencji, której działalność była źródłem tworzenia prawa. W ten sposób - przez kazuistykę - ars boni et aequi stała się jednak wskazówką odnoszącą się do wielu takich spraw, a więc w rezultacie ogólną wytyczną stosowania prawa ${ }^{25}$.

Dodać jednak trzeba, że na aequitas, ius, iustitia czy iuris praecepta Rzymianie patrzyli dość trzeźwo, nie dając się ponosić pięknu sformułowania czy tylko etycznym walorom. Stąd takie zastrzeżenia, jak np. Non omne quod licet hone-

25 Por. W. Litewski, Jurysprudencja rzymska, Kraków 2000, s. 103-107; idem, Podstawowe wartości prawa rzymskiego, Kraków 2001, s. 48. 
stum est („Nie wszystko, co nawet [prawnie] dozwolone, jest uczciwe”) ${ }^{26}$. Jest to ważna wskazówka interpretacyjna przy stosowaniu prawa oraz przy ocenie, czy zastosowanie prawa, nawet zgodne $\mathrm{z}$ jego literą, nie jest $\mathrm{w}$ rezultacie sprzeczne z etyką i poczuciem sprawiedliwości, a także czy nie prowadzi do osiągnięcia nieuczciwych celów oraz do nadużycia prawa. W nieco innym rozumieniu sentencja ta oznacza, że nie wszystko jest uczciwe, co nawet nie jest zakazane prawem ${ }^{27}$. Taka interpretacja ma sens zwłaszcza przy rozpowszechnionym dzisiaj przekonaniu, że dozwolone jest wszystko, co nie jest prawnie zakazane. Ale z kolei nie wszystko, co nawet nie jest prawem zabronione, jest uczciwe, zgodne z normami etycznymi czy dobrymi obyczajami ${ }^{28}$.

III.

Aequitas (słuszność, stosowność) zajmuje zresztą osobne miejsce. Idea słuszności była głęboko zakorzeniona w rzymskiej myśli społecznej i prawnej oraz była oryginalnym tworem rzymskim ${ }^{29}$. Sam termin aequitas pochodzi od łacińskiego słowa aequus (-a, -um), oznaczającego 'równy, słuszny, bezstronny'. W konsekwencji wskazuje on na słuszność w sensie równości, równowagi, równouprawnienia, zachowania proporcji oraz równego wyważenia racji stron. W symbolicznych przedstawieniach na rzeźbach i monetach aequitas jest ukazywana jako kobieta w długiej, powłóczystej szacie, zawsze z wagą w ręce. Waga symbolizuje właśnie równość, bezstronne wyważenie argumentów obu stron, a w rezultacie przyznanie każdemu tego, co mu się słusznie należy - suum cuique ${ }^{30}$.

Od Cycerona następuje pewne wymieszanie pojęć aequitas i iustitia, co z czasem przejęli również rzymscy juryści (np. cytowany już Ulpianus D. 1.1.1.1) i cesarze ${ }^{31}$. W konsekwencji waga przeszła z rąk aequitas do iustitia jako rzymskiej bogini sprawiedliwości. Ostatecznie przyjmuje się, że aequitas wynikała obiektywnie z natury i naturalnej równości społecznej; oznaczała słuszność jako wyraz społecznej sprawiedliwości wyrównawczej przyznania każdemu tego, co

26 Paulus D. 50,17,144 pr.; Modestinus D. 50,17,197; K. Burczak, A. Dębiński, M. Jońca, op. cit., s. 173 (nr 165); T. Palmirski, O różnych regułach dawnego prawa, „Zeszyty Prawnicze” 2007, z. 7.1, s. 324, 360. Ponadto: D. Liebs, op. cit., s. 139 (nr 124); Regulae iuris ..., s. 96.

27 U. von Lübtow, De iustitia..., s. 543 i n.

28 W tym sensie uzupełnia przytoczoną sentencję wypowiedź Modestyna (D. 50,17,197): Semper in coniunctionibus non solum quod liceat consideranda est, sed et quid honestum est („W odniesieniu do związków [małżeńskich] należy brać zawsze pod rozwagę nie tylko to, co jest [prawnie] dozwolone, lecz także to, co jest uczciwe i godne"). Zob. D. Liebs, op. cit., s. 139-140.

29 Regulae iuris..., s. 91; M. Kuryłowicz, Wokót pojęcia aequitas..., s. 23-25.

30 Por. ostatnio: L. Ostwaldt, Aequitas und iustitia. Ihre Ikonographie in Antike und Früher Neuzeit, Magdeburg 2009 (z obszernym wykazem literatury na s. 369-396).

31 Konstantyn C. 3,1,8 z 314 r.: Placuit in omnibus rebus praecipuam esse iustitiae aequitatisque quam stricti iuris rationem. 


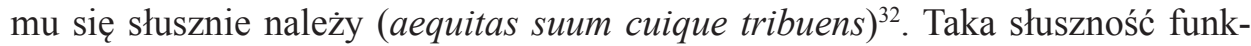
cjonuje niezależnie od prawa (ius). Iustitia oznaczała natomiast cnotę przynależną sędziemu, który powinien wydawać wyroki sprawiedliwe w sensie zgodności z obowiązującym prawem, zmierzającym w założeniu do unormowania ładu społecznego. Ius opiera się bowiem w tej koncepcji nie na idei równości, lecz na hierarchii i porządku społecznym. Później aequitas oznacza również prawo równe dla wszystkich obywateli, w założeniu obiektywnie słuszne (ius aequum). W tym sensie zbliża się do iustitia i jednolitej koncepcji prawa słusznego i sprawiedliwego (iustum et aequum). Juryści rzymscy, swoim zwyczajem, pojęć tych nie zdefiniowali, ale doskonale wyczuwali istotę słuszności, głównie jako czynnika służącego do łagodzenia rygorów prawa. W rezultacie, jeśli przyjąć, że iustitia oznacza sprawiedliwość i od niej, jak uważa Ulpian (D. 1,1,1 pr.) wywodzi się prawo (est autem a iustitia appelatum), a prawo - według definicji Celsusa - to umiejętność tworzenia i stosowania tego, co dobre (bonum) i słuszne (aequum), to filozoficzno-prawne koło się zamyka ${ }^{33}$.

IV.

Aequitas była pierwotnie pojęciem z filozofii naturalnej, rozumiano ją jako wspólne przekonanie właściwe wszystkim ludziom, a więc zgodne z naturą. Takie ujęcie wyraźne jest również w tekstach prawniczych. Tak np. Pomponius (D. 12,6,14) zauważa w odniesieniu do idei bezpodstawnego wzbogacenia: Nam hoc natura aequum est neminem cum alterius detrimento fieri locupletiorem (,Albowiem słuszne jest z natury, by nikt nie stał się bogatszym ze szkodą drugiego") ${ }^{34}$. Myśl była ważna, skoro powraca u Justyniana w tytule Digestów o regułach prawa: Iure naturae aequum est neminem cum alterius detrimento et iniuria fieri locupletiorem ${ }^{35}$. Z kolei Gaius (D. 38,8,2) odnosi naturalną słuszność do dziedziczenia kognatów: Hac parte proconsul naturali aequitate motus omnibus cognatis promittit bonorum possessionem, quos sanguinis ratio vocat ad hereditatem, licet iure civili deficiant („W tej części [edyktu prowincjonalnego] prokonsul,

32 W. Waldstein, Ist das „ius suum cuique“ eine Leerformel?, [w:] Ius Humanitatis. Festschrift A. Verdross, Berlin 1980, s. 292 i n.; idem, „Aequitas “ und „,summum ius “, [w:] Tradition und Fortentwicklung im Recht. Festschrift für 90. Geburtstag U. von Lüibtow, Berlin 1991, s. 23 i n.

33 Poza pozycjami już wymienionymi w przypisie 4 zob. A. Polaček, Ius est ars aequi et boni, [w:] Studi in onore di Biscardi, t. 2, Milano 1982, s. 28 i n.; M. Kaser, Das Römische Privatrecht, Bd. 1, München 1975, s. 194-195 i przywołana tam literatura.

34 Por. Regulae iuris ..., s. 59-60; K. Burczak, A. Dębiński, M. Jońca, op. cit., s. 46 (nr 176).

35 Pomponius D. 50,17,206: „Jest słuszne z natury, aby nikt nie bogacił się ze szkodą i krzywdą innego". Powołuje się na nią również papież Bonifacy VIII w Liber sextus decretalium, choć już bez odwołania do natury i aequitas. Zob. A. Dębiński, Kościót i prawo rzymskie, Lublin 2008, s. 168 (nr 48). Por. T. Palmirski, O różnych regułach dawnego prawa, „Zeszyty Prawnicze” 2007, z. 7.2, s. $312,342$. 
działając pod wpływem naturalnej słuszności, przyrzeka przyznać dziedziczenie tym wszystkim, u których uzasadnia to wzgląd na więzy krwi, chociaż prawo cywilne tego odmawia”). Względami naturalnej słuszności uzasadnia także ten jurysta nabycie prawa własności - Gaius D. 41,1,9,3: Nihil enim tam conveniens est naturali aequitati quam voluntatem domini volentis rem suam in alium transferre ratam haberi („Nic bowiem nie jest tak zgodne z naturalną słusznością, jak uznanie woli właściciela, który chce przenieść swoją rzecz na inną osobę"). Paulus w D. 49,15,19 pr. odwołuje się z kolei do naturalnej słuszności przy ocenie skutków prawnych powrotu obywatela rzymskiego z niewoli wojennej: Idque naturali aequitate introductum est, ut qui per iniuriam ab extraneis detinebatur, is, ubi in fines suos redisset, pristinum ius suum reciperet (,Jest bowiem wyprowadzone z naturalnej słuszności, aby ten, kto był zatrzymywany niesprawiedliwie przez obcych, otrzymał po powrocie $\mathrm{w}$ granice swojego państwa całe swoje poprzednie prawo"). Ulpian (D. 43,26,2,1-2) wypowiada się w kwestii edyktu dotyczącego zwrotu rzeczy wziętej w precarium: Hoc interdictum restitutorium est. Et naturalem habet in se aequitatem, namque precarium revocare volenti competit: est enim natura aequum tamdiu te liberalitate mea uti, quamdiu ego velim, et ut possim revocare, cum mutavero voluntatem (,Ten interdykt ma na celu przywrócenie stanu pierwotnego. I jest on oparty na naturalnej słuszności, gdyż przysługuje temu, kto chce odwołać prekarium. Jest bowiem w sposób naturalny czymś słusznym to, że tak długo korzystasz z mojej hojności, jak długo ja tego chcę, i że mogę odwołać prekarium, gdy zmienię swoją wolę") ${ }^{36}$. W ogólności na źródło słuszności w prawie naturalnym wskazuje Paulus D. 1,1,11: Ius pluribus modis dicitur: uno modo, cum id quod semper aequum ac bonum est ius dicitur, ut est ius naturale („Prawo określa się na różne sposoby: w jednym prawem jest to, co zawsze dobre i słuszne, a takim jest prawo naturalne").

Prawne znaczenia słuszności widoczne są ponadto $\mathrm{w}$ odniesieniach pojęcia aequitas do różnych sytuacji oraz instytucji prawnych. Tak np. interesująca jest wypowiedź Marcianusa przy kwestii rozliczeń posagowych, gdy jurysta czyni dodatkowo uwagę o wynikającej ze słuszności równości osób wobec prawa bez względu na płeć (Modestinus D. 42,1,20 pr.: quod et in persona mulieris aequa lance servari aequitatis suggerit ratio [,,wzgląd na słuszność nakazuje także wobec kobiety stosować równą miarę"]). Do kontraktu spółki odnosi się wypowiedziana przez Ulpiana (D. 17,2,55) reguła: Aequum est, ut quis participavit lucrum, participet et damnum (,Jest słuszne, aby ten, kto uczestniczy w zysku, uczestniczył także w stracie") ${ }^{37}$. Podobnie z tekstu Marcellusa D. 4,1,7 pr., dotyczącego

36 Tłumaczenie według: Digesta Iustiniani. Digesta justyniańskie, red. T. Palmirski, t. 6.2, Kraków 2016, s. 307.

37 Podobnie w Instytucjach Gaiusa (G. 3,149) oraz w Instytucjach justyniańskich (Inst. $3,25,2)$. 
kwestii stosowania pozaprocesowego środka ochrony prawnej, jakim była restitutio in integrum (przywrócenie do stanu pierwotnego), wyabstrahowana została w D. 50,17,183 reguła: Etsi nihil facile mutandum est ex sollemnibus, tamen ubi aequitas evidens poscit, subveniendum est („I chociaż nie jest łatwo zmienić coś z formalistyki [prawa cywilnego], to jednak tam, gdzie wzywa oczywista słuszność, należy przyjść z pomocą") $)^{38}$. Słuszność występuje również przy odpowiedzialności według prawa cywilnego (np. G. 4,116: Saepe enim accidit, ut quis iure civili teneatur, sed iniquum sit eum iudicio condemnari [„Często bowiem zdarza się, że ktoś ponosi odpowiedzialność według prawa cywilnego, ale byłoby niesłuszne zasądzenie go w procesie"]). Procesowy aspekt ma też prawo do obrony swoich racji (Papinianus D. 44,4,12: Qui aequitate defensionis infringere actionem potest [„Można osłabić powództwo słusznością swej obrony”]). Także w formułkach procesowych rozmaitych skarg (zwłaszcza dobrej wiary, actiones bonae fidei) zawarta była wskazówka dla sędziego, aby zasądził to i tyle, co zgodne z uczciwością i słusznością (np. Ulpianus D. 21,1,42: Quanti bonum aequum iudici videbitur, condemnetur [„Niech zostanie zasądzone tyle, ile wydaje się sędziemu dobre i słuszne"]).

W źródłach występuje również aequitas civilis (w odróżnieniu od aequitas naturalis), rozważana np. w szczegółowej sprawie odpowiedzialności wyzwolonego w testamencie niewolnika, który okradł spadek (Ulpianus D. 47,4,1,1: Haec autem actio, ut Labeo scripsit, naturalem potius in se quam civilem habet aequitatem [,,Ta zaś skarga zawiera w sobie, jak napisał Labeo, więcej naturalnej słuszności niż z prawa cywilnego"]). Aequitas rei to słuszność rozważanej sprawy (Paulus D. 36,1,76,1: Imperator autem noster motus et aequitate rei et verbis testamenti... [,Zaś nasz cesarz poruszony słusznością sprawy i słowami testamentu...”]), z kolei aequitas actionis oznacza słuszność jako podstawę powództwa (Ulpianus D. 47,10,1,1: Secundum haec ergo aequitas actionis omnem metum eius abolere videtur, ubicumque contra aequum quis venit [„Uważa się, że zgodnie z tym słuszność skargi znosi wszelką obawę, ilekroć ktoś występuje przeciwko temu, co słuszne"]). Chodzi tu o actio iniuriarum, deliktową skargę z powodu zniesławienia lub zniewagi. Skarga ta, jak zauważa wcześniej w przytoczonym tekście Ulpian, oparta była w ogóle na poczuciu przyzwoitości i słuszności (ex bono et aequo est). Zwrot aequitas iudicii został użyty ponadto w odniesieniu do słuszności w postępowaniu o podział współwłasności (Paulus D. 10,14,1: aequitate ipsius iudicii). W pytaniu Cur species actionis aequitatem divisionis excludit? (Papinianus D. 27,7,7: „Dlaczego rodzaj skargi miałby wykluczać zasadność podziału?”) chodzi z kolei o kwestię podziału roszczeń między kilku poręczycie-

38 Por. Digesta Iustiniani, t. 7.2 (2017), s. 435: „Chociaż nie wolno swobodnie zmieniać formalnych wymogów prawnych, jednak tam, gdzie zasady słuszności wyraźnie się tego domagają, należy przyjść z pomocą". 
li, a argumentem jest słuszność, która uzasadnia dopuszczenie takiego rozdziału skarg. Wzgląd na aequitas może stanowić również podstawę do odmówienia np. przywrócenia utraconych wskutek capitis deminutio praw (Paulus D. 4,5,7,3: nulla restitutionis aequitas est).

Te wyrywkowe przykłady pozwalają zauważyć obecność aequitas w różnorodnych kwestiach dogmatycznych i procesowych rzymskiego prawa prywatnego. Stosownie do rozważanej materii może ona przybierać różne znaczenie.

Pojęciowo aequitas łączona jest także z podobnymi znaczeniowo określeniami, jak np. humanitas - ludzka życzliwość, słuszność w postępowaniu człowieka. Tak u Paulusa w D. 28,5,85 pr.: Et humanius est et magis aequitatis ratione subnixum („I tak jest po ludzku i bardziej oparte na zasadzie słuszności”) ${ }^{39}$.

Najwyraźniej i konsekwentnie odwoływał się w Rzymie do aequitas edykt pretorski. W rezultacie to właśnie prawo pretorskie, stosowane praktycznie w procesie, stało się głównym nurtem słusznościowym w państwie rzymskim ${ }^{40}$. Pretor nie miał władzy ustawodawczej, ale wyposażony w ius edicendi (czyli prawo magistratury do wydawania edyktów) oraz we władzę jurysdykcyjną swobodnie obracał się na pograniczu tworzenia i stosowania prawa, kierując się niekiedy względami słuszności. Tę rolę prawa pretorskiego wyraźnie odnotowują teksty prawnicze, np. autorstwa Ulpiana D. 4,4,1 pr.: Hoc edictum praetor naturalem aequitatem secutus proposuit („Ten edykt ogłosił pretor, postępując za naturalną słusznością")" habet naturalem („Ten tytuł [edyktu] zawiera w sobie naturalną słuszność” w kwestii z zakresu dziedziczenia przeciwtestamentowego); D. 2,14,1 pr.: Huius edicti aequitas naturalis est (,Widoczna jest naturalna słuszność tego edyktu" ${ }^{42}$. Chodziło tu głównie o korygowanie i uzupełnianie w różnych kwestiach prawnych formalistycznego ius civile. $\mathrm{W}$ tym sensie prawo pretorskie oznaczało prawo słuszne (ius aequum).

39 H. Kupiszewski, Humanitas a prawo rzymskie, „Prawo Kanoniczne” 1977, nr 1-2, s. 288 310; idem, Prawo rzymskie a wspótczesność, Warszawa 2013, s. 176-196.

40 Por. W. Wołodkiewicz, M. Zabłocka, Prawo rzymskie. Instytucje, Warszawa 2014, s. 12-14 (z wykazem dalszej literatury na s. 12). Ponadto m.in. A. Stelmachowski, Zarys teorii prawa cywilnego, Warszawa 1998, s. 109-112; R. Sobański, Stuszność w prawie, „Państwo i Prawo” 2001, z. 8, s. $3-12$.

${ }^{41}$ Chodziło o udzielanie pomocy osobom małoletnim, niedysponującym jeszcze należytym rozeznaniem w kwestiach prawnych.

$42 \mathrm{~W}$ kwestii dopuszczalności zawierania umów nieformalnych (pacta). W dalszym ciągu Ulpian zaznacza: Quid enim tam congruum fidei humanae, quam ea quae inter eos placuerunt servare? („Cóż bowiem bardziej ma związek z ludzkim zaufaniem niż przestrzeganie tego, co ludzie między sobą ustalili?”). Tak ocenia rolę pretora np. Gaius w swoich Instytucjach (G. 3,25): Sed hae iuris iniquitates edicto praetoris emendatae sunt (,Ale te niesłuszności prawne [prawa cywilnego] zostały naprawione przez edykt pretora"). 
Bez wątpienia można zatem pretora i jego działalność uznać za najważniejszy w tym okresie czynnik wprowadzania zasad słuszności do rzymskiego życia prawnego. Ale nie można zapominać, że za wybieranymi na roczne kadencje pretorami silnie stała działalność rzymskiej jurysprudencji. To spośród uczonych prawników pretorzy dobierali sobie doradców i korzystali z ich fachowych porad. Takie konsylium miało z reguły charakter trwały - juryści pozostawali przez dłuższy czas przy zmieniających się pretorach, zapewniając w ten sposób wysoki poziom naukowy stosowanego prawa (pretorskiego), trwałość stanu prawnego oraz w miarę jednolite orzecznictwo. Szczególna rola przypadała więc jurysprudencji, określanej również poprzez słuszność i sprawiedliwość: Iuris prudentia est divinarum atque humanarum rerum notitia, iusti atque iniusti scientia (,,Jurysprudencja jest znajomością praw boskich i ludzkich oraz wiedzą o tym, co zgodne i niezgodne z prawem" - Ulpianus D. 1,1,10,2; Inst. 1,1,1) ${ }^{43}$. Zadanie jej widzi dalej rzymski jurysta $\mathrm{w}$ uprawianiu sprawiedliwości oraz upowszechnianiu dobra i słuszności. W ten sposób - jak twierdzi Ulpian - prawnicy pełnią funkcję kapłanów prawa i sprawiedliwości:

UIp. D. 1,1,1: Cuius merito quis nos sacerdotes appellet: iustitiam namque colimus et boni et aequi notitiam profiteamur, aequum ab iniquo separantes, licitum ab illicito discernentes, bonos non solum metu poenarum, verum etiam praemiorum quoque exhortatione efficere cupientes, veram nisi fallor philosophiam, non simulatam affectantes.

(Dlatego ktoś słusznie nazwie nas kapłanami, ponieważ czcimy sprawiedliwość, wyznajemy dobro i słuszność, oddzielamy to, co szlachetne od tego, co niesłuszne, rozgraniczamy między tym, co dozwolone a niedozwolone, pragniemy sprawić, by ludzie byli dobrzy nie tylko ze względu na obawę przed karami, ale także ze względu na zachętę, jaką stanowią nagrody; zajmujemy się, jeśli się nie mylę, filozofią rzeczywistą, a nie pozorną) $)^{44}$.

Powracają tu elementy zawarte w przekazanych definicjach prawa i sprawiedliwości: iustitia oraz bonum et aequum, z podkreśleniem jednak praktycznej strony działalności jurystów, którzy uprawiają rzeczywistą (tj. nastawioną na użyteczne cele) filozofię, a nie tylko prowadzą teoretyczne rozważania. Wskazane pojęcia nie są więc pustymi formułami retorycznymi, lecz są wyrazem twórczej wykładni prawa w jego stosowaniu ${ }^{45}$. Wskazują one na to, co w stosowaniu prawa

43 Por. Regulae iuris..., s. 53-56. Ponadto: M. Kuryłowicz, Prawo rzymskie. Historia..., s. 65-81; W. Litewski, Jurysprudencja ..., s. 103-107.

44 Por. M. Kuryłowicz, Sacerdotes iustitiae, [w:] Ecclesia et Status. Księga jubileuszowa z okazji 40-lecia pracy naukowej profesora Józefa Krukowskiego, red. A. Dębiński, K. Orzeszyna, M. Sitarz, Lublin 2004, s. 699-713 i przywołana tam literatura.

45 Por. na ten temat m.in. M.H. Tapani Klami, Sacerdotes iustitiae. Rechtstheoretische und historisch-methodologische Bemerkungen über Entstehung des römischen Rechtspositivismus, Turku 1978; M. Schermaier, Ulpian als „,wahrer Philosoph“, [w:] Ars boni et aequi. Festschrift für W. Waldstein, Stuttgart 1993, s. 303-322; W. Waldstein, Zum Problem der vera philosophia bei Ulpian, [w:] Collatio Iuris Romani. Études dédiées á H. Ankum, Amsterdam 1995, s. 607-617. 
jest społecznie, moralnie i prawnie dobre i słuszne. W ten sposób uzyskały rangę instrumentu interpretacji prawa oraz nabrały znaczenia postulatu stosowania prawa równego i sprawiedliwego dla wszystkich ${ }^{46}$.

Jurysta musiał więc posiadać znajomość wszelkich spraw świata boskiego i ludzkiego, a także wiedzę o prawie, o tym, co z nim zgodne, a co niezgodne, co sprawiedliwe i niesprawiedliwe. Niewątpliwie uprawianie działalności prawniczej wymagało znajomości realiów życia, biegłości w prawie oraz przekonania co do zasad słuszności i sprawiedliwości. Odróżnić też trzeba iuris scientia od iuris prudentia. Nauka (scientia) prawa miała charakter teoretycznej wiedzy o prawie, iuris prudentia (mądrość, uczoność, biegłość w prawie) zaś miała aspekt wiedzy praktycznej ${ }^{47}$.

Przy nieuchronnej z czasem modernizacji instytucji prawnych ,fundamentalną tezą europejskiej kultury" (prawnej) stała się idea słuszności, niesiona m.in. przez prawo rzymskie ${ }^{48}$. „Cała jej [tj. europejskiej kultury] historia - pisze Remigiusz Sobański - to zmaganie się o przekonującą odpowiedź na pytanie, co to jest słuszne prawo, jak można je poznać i jak je zrobić"49. Wcześniej już Andrzej Stelmachowski zauważał ,ów trudno uchwytny, a historycznie fascynujący czynnik, jakim była słuszność” oraz „trwające od co najmniej paru tysięcy lat wysiłki, by jakoś pogodzić podstawowe sprzeczności między tęsknotą do jasności i stabilizacji prawa a dążeniem do jego uelastycznienia, dostosowania do warunków i potrzeb chwili; między dążeniem do stworzenia reguł określających ramy organizacyjne życia społecznego ogółu a uszanowaniem potrzeb i uczuć jednostki”"50.

Niezaprzeczalną historyczną rolę w ukształtowaniu tego nurtu odegrało prawo rzymskie.

46 Por. m.in. J. Maifeld, op. cit.; W. Waldstein, Aequitas und..., s. 23 i n. Istotną rolę odegrało tu również ius gentium, odwołujące się do prawa naturalnego oraz do naturalis aequitas. Por. M. Kaser, Ius gentium, Köln 1993, s. 54-67.

47 W. Litewski, Jurysprudencja ..., s. 8.

48 Por. także: M. Kuryłowicz, The Importance of Roman Law in European Legal Culture, [w:] Scripta minora selecta. Ausgewählte Schriften zum römischen Recht, Lublin 2014, s. 268-279 i przywołana tam literatura.

49 R. Sobański, Kultura prawna Europy, „Studia Europejskie (Centrum Europejskie Uniwersytetu Warszawskiego)" 1998, nr 3, s. 128; idem, Stuszność..., s. 3-12.

50 A. Stelmachowski, Wstęp do teorii prawa cywilnego, Warszawa 1984, s. 137; idem, Zarys teorii prawa..., s. 109-112. 


\section{BIBLIOGRAFIA}

Amielańczyk K., Obecność i znaczenie zasady stuszności w rzymskim prawie karnym, „Studia Iuridica Lublinensia" 2011, t. 15.

Bojarski W., Dajczak W., Sokala A., Verba iuris. Reguły i kazusy prawa rzymskiego, Torun 2007.

Burczak K., Dębiński A., Jońca M., Eacińskie sentencje i powiedzenia prawnicze, Warszawa 2013.

Czecharowski M., Iustitia non debet claudicare, ,Jurysta” 2002, nr 7-8.

Dębiński A., Kościót i prawo rzymskie, Lublin 2008.

Dobrowolska M., Trybunat Koronny w Lublinie 1578-1794, Lublin 1994.

Gallo F., Diritto e giustizia nel titolo primo dei Digesta, "Studia et Documenta Historiae et Iuris" 1988, Vol. 56.

Hausmaninger H., Publius Juventius Celsus: Persönlichkeit und juristische Argumentation, [w:] Aufstieg und Niedergang der Römischen Welt, Bd. 2, Berlin-New York 1976.

Ilustrowany przewodnik po Lublinie, Lublin 1931 (reprint).

Jońca M., Źli sędziowie, czyli czego nas uczy historia antyczna, „Dziennik Gazeta Prawna”, 16.08.2016.

Kaser M., Das Römische Privatrecht, Bd. 1, München 1975.

Kaser M., Ius gentium, Köln 1993.

Kupiszewski H., Humanitas a prawo rzymskie, „Prawo Kanoniczne” 1977, nr 1-2.

Kupiszewski H., Prawo rzymskie a wspótczesność, Warszawa 2013.

Kuryłowicz M., Alterum non laedere i uniwersalność rzymskich zasad prawa, [w:] Państwo i prawo $w$ dobie globalizacji, red. S. Sagan, Rzeszów 2011.

Kuryłowicz M., Das römische Recht als Ideal eines richtigen und gerechten Rechts, "Comparative Law Review” 2013, Vol. 16, DOI: https://doi.org/10.12775/CLR.2013.024.

Kuryłowicz M., Etyka i prawo w sentencjach rzymskich jurystów, [w:] W kręgu problematyki władzy, państwa i prawa (księga jubileuszowa prof. H. Groszyka), red. J. Malarczyk, Lublin 1996.

Kuryłowicz M., Ex iniuria ius non oritur. Szkic do dziejów zasady, [w:] Ius est a iustitia appelatum. Ksiega jubileuszowa dedykowana Profesorowi Tadeuszowi Wiśniewskiemu, red. T. Ereciński, J. Gudowski, M. Pazdan, M. Tomalak, Warszawa 2017.

Kuryłowicz M., Prawa antyczne. Wyktady z historii najstarszych praw świata, Lublin 2006.

Kuryłowicz M., Prawo rzymskie. Historia - tradycja - wspótczesność, Lublin 2003.

Kuryłowicz M., Prawo rzymskie jako ideat prawa dobrego $i$ sprawiedliwego, „Przegląd Prawa Egzekucyjnego" 2010/2011, t. 10.

Kuryłowicz M., Rzymskie sentencje prawnicze o człowieku, sprawiedliwości i prawie, „Palestra” $1988, \mathrm{nr} 7$.

Kuryłowicz M., Sacerdotes iustitiae, [w:] Ecclesia et Status. Księga jubileuszowa z okazji 40-lecia pracy naukowej profesora Józefa Krukowskiego, red. A. Dębiński, K. Orzeszyna, M. Sitarz, Lublin 2004.

Kuryłowicz M., The Importance of Roman Law in European Legal Culture, [w:] Scripta minora selecta. Ausgewählte Schriften zum römischen Recht, Lublin 2014.

Kuryłowicz M., Wokół pojęcia aequitas w prawie rzymskim, "Studia Iuridica Lublinensia" 2011, t. 15.

Liebs D., Lateinische Rechtsregeln und Rechtssprichwörter, München 1986.

Litewski W., Jurysprudencja rzymska, Kraków 2000.

Litewski W., Podstawowe wartości prawa rzymskiego, Kraków 2001.

Longchamps de Bérier F., Nadużycie prawa $w$ świetle rzymskiego prawa prywatnego, Wrocław 2004 (wyd. 2, Wrocław 2007).

Lübtow U. von, De iustitia et iure, ,Savigny-Zeitschrift für Rechtsgeschichte. Romanistische Abteilung“" 1948, Bd. 66(1), DOI: https://doi.org/10.7767/zrgra.1948.66.1.458. 
Lübtow U. von, Die Anschauungen der römischen Jurisprudem über Recht und Gerechtigkeit, [w:] Studi in onore di C. Sanfilippo, t. 4, Milano 1985.

Łacińska terminologia prawnicza, red. J. Zajadło, Warszawa 2009.

Łazarska A., Rzetelny proces cywilny, Warszawa 2012.

Maifeld J., Die ,, aequitas “ bei L. Neratius Priscus, Trier 1991.

Nörr D., Cicero-Zitate bei den klassischen Juristen. Zur. Bedeutung literarischer Zitate bei den Juristen und zur Wirkungsgeschichte Ciceros, [w:] Ciceroniana. Atti del III Colloquium Tullianum, Roma 1978.

Ostwaldt L., Aequitas und iustitia. Ihre Ikonographie in Antike und Früher Neuzeit, Magdeburg 2009.

Palmirski T., O różnych regułach dawnego prawa, „Zeszyty Prawnicze” 2006, z. 6.2.

Palmirski T., O różnych regułach dawnego prawa, „Zeszyty Prawnicze” 2007, z. 7.1.

Palmirski T., O różnych regułach dawnego prawa, „Zeszyty Prawnicze” 2007, z. 7.2.

Polaček A., Ius est ars aequi et boni, [w:] Studi in onore di Biscardi, t. 2, Milano 1982.

Polaček A., Zum Gerechigkeitsgedanken im römischen Recht, „Savigny-Zeitschrift für Rechtsgeschichte. Romanistische Abteilung“ 1960, Bd. 77(1),

DOI: https://doi.org/10.7767/zrgra.1960.77.1.160.

Regulae iuris. Łacińskie inskrypcje na kolumnach Sąu Najwyższego Rzeczypospolitej Polskiej, red. W. Wołodkiewicz, Warszawa 2001.

Schermaier M., Ulpian als ,,wahrer Philosoph “, [w:] Ars boni et aequi. Festschrift für W. Waldstein, Stuttgart 1993.

Sobański R., Kultura prawna Europy, „Studia Europejskie (Centrum Europejskie Uniwersytetu Warszawskiego)" 1998, nr 3.

Sobański R., Stuszność w prawie, „Państwo i Prawo” 2001, z. 8.

Stelmachowski A., Wstep do teorii prawa cywilnego, Warszawa 1984.

Stelmachowski A., Zarys teorii prawa cywilnego, Warszawa 1998.

Stępkowski A., Maksymy prawne na Wyspach Brytyjskich, [w:] Lacińskie paremie w europejskiej kulturze prawnej i orzecznictwie sądów polskich, red. W. Wołodkiewicz, J. Krzynówka, Warszawa 2001.

Tapani Klami M.H., Sacerdotes iustitiae. Rechtstheoretische und historisch-methodologische Bemerkungen über Entstehung des römischen Rechtspositivismus, Turku 1978.

Tokarczyk R., Przykazania etyki prawniczej. Księga myśli, norm i rycin, Warszawa 2009.

Voci P., Ars boni et aequi, "INDEX" 1999, No. 27.

Wacke A., Audiatur et altera pars. Juristische Arbeitsblätter, Berlin 1980.

Waldstein W., ,A Aequitas “ und ,summum ius “, [w:] Tradition und Fortentwicklung im Recht. Festschrift für 90. Geburtstag U. von Lüibtow, Berlin 1991.

Waldstein W., Ist das ,,ius suum cuique“ eine Leerformel?, [w:] Ius Humanitatis. Festschrift A. Verdross, Berlin 1980.

Waldstein W., Zu Ulpians Definition der Gerechtigkeit, [w:] Festschrift für Werner Flume, Köln 1978.

Waldstein W., Zum Problem der vera philosophia bei Ulpian, [w:] Collatio Iuris Romani. Études dédiées á H. Ankum, Amsterdam 1995.

Witkowski W., Lublin Trybunalski, [w:] Lublin w dziejach i kulturze Polski, Lublin 1997.

Wołodkiewicz W., Zabłocka M., Prawo rzymskie. Instytucje, Warszawa 2014. 


\section{SUMMARY}

Aequitas (equity) was part of the Roman conception of law (ius est ars boni et aequi), which in turn was, according to Roman jurists, grounded in justice (iustitia). The ideas of aequitas and iustitia in the broad sense are also found in various Latin legal phrases, a selection of which is cited in this article. They constitute significant arguments and topics in legal reasoning and justification even today. Some criteria of equity and justice can also be seen in how the concepts of aequitas or iustitia are applied to different situations (cases) or legal institutions (examples in the article). The most evident reference to aequitas in Rome was in the Praetor's Edict and, consequently, it was the Praetor's law, practically enforced in court, that turned into the main equity tendency in Roman law. Praetors were supported by the strongly deliberative activity of Roman jurisprudence. As a result, lawyers occupied the already accepted role of priests of law and justice (sacerdotes iustitiae). The discussed concepts were thus an expression of a creative approach to statutory interpretation. They stressed what was socially, morally and legally good, right and just, in the application of law. The idea of equity, conveyed by Roman law, eventually became a fundamental thesis of European legal culture.

Keywords: equity; justice; Roman law; Roman jurisprudence

\section{STRESZCZENIE}

Aequitas (słuszność) była częścią rzymskiego pojęcia prawa (ius est ars boni et aequi), które w koncepcji rzymskiej wywodziło się od sprawiedliwości (iustitia). Słuszność i sprawiedliwość w szerszym znaczeniu można odnaleźć w wielu sentencjach i regułach prawa rzymskiego, przytoczonych w niniejszym artykule. Tworzyły one ważne również dzisiaj argumenty i topiki w rozumowaniach oraz uzasadnieniach prawniczych. Kryteria słuszności i sprawiedliwości stosowane były ponadto przez jurystów rzymskich przy rozstrzyganiu konkretnych przypadków prawnych (kazusów - przykłady w tekście). Najwyraźniej odwoływał się w Rzymie do aequitas edykt pretorski. W rezultacie to właśnie prawo pretorskie, stosowane praktycznie w procesie, stało się głównym nurtem słusznościowym w prawie rzymskim. Za pretorami stała silnie działalność rzymskiej jurysprudencji, zmierzającej w ogólności do realizowania sprawiedliwości oraz upowszechniania zasad dobra i słuszności. W ten sposób juryści w swej praktycznej działalności pełnili rolę kapłanów prawa i sprawiedliwości (sacerdotes iustitiae). Idea słuszności, niesiona przez prawo rzymskie, stała się z czasem fundamentalną tezą europejskiej kultury prawnej.

Słowa kluczowe: słuszność; sprawiedliwość; prawo rzymskie; jurysprudencja rzymska 